\title{
Operating Conditions of A Locally Made Fixed-Bed Incinerator, a Case Study of Bagamoyo - Tanzania
}

\author{
Arthur Mngoma Omari ${ }^{2,}$, , Geoffrey Reuben John ${ }^{1}$, Karoli Nicholas Njau ${ }^{3}$, Peter Lucas Mtui ${ }^{1}$ \\ ${ }^{1}$ College of engineering and Technology, University of Dar es Salaam, Dar es Salaam, Tanzania \\ ${ }^{2}$ College of engineering and Technology, Mbeya University of Science and Technology, Mbeya Tanzania \\ ${ }^{3}$ School of Materials, Energy, Water and Environmental Sciences, Nelson Mandela African Institution of Science and Technology, Arusha \\ Tanzania
}

\section{Email address:}

mngoma2003@hotmail.com (A. M. Omari), geofrey.john@nm-aist.ac.tz (G. R. John), karoli.njau@nm-aist.ac.tz (K. N. Njau), plmtui@yahoo.com (P. L. Mtui)

\section{To cite this article:}

Arthur Mngoma Omari, Geoffrey Reuben John, Karoli Nicholas Njau, Peter Lucas Mtui. Operating Conditions of A Locally Made Fixed-Bed Incinerator, a Case Study of Bagamoyo - Tanzania. International Journal of Environmental Monitoring and Analysis.

Vol. 3, No. 2, 2015, pp. 80-90. doi: 10.11648/j.ijema.20150302.17

\begin{abstract}
To minimize the pollution from municipal solid waste incinerators, the study of operating conditions is imperative. The local design incinerators can be used for high performance combustion and minimize pollutions. The incinerator located at Bagamoyo hospital in Tanzania is used as a pilot for this experiment. The emission and operating conditions shows that the performance of incinerator is at maximum peak of about $70 \%$ when the oxygen at exit is about $6.9 \%$ and when secondary temperature is between 1073 and $1173 \mathrm{~K}$ and primary temperature maintained at $673 \mathrm{~K}$. The experiment shows that when the primary chamber temperature increases beyond $673 \mathrm{~K}$, the secondary temperature decreases this is due to complete combustion at primary chamber which will cause insufficient incomplete gases and therefore limited combustible gases to burn.
\end{abstract}

Keywords: Waste incineration, emission, fixed bed, solid waste

\section{Introduction}

Waste is material or object which the holder may dispose-off or plan to dispose-off [1]. Municipal solid waste generation has been increased as the results of human development and population growth. This is a big challenge of waste disposal in most countries [2]. The rate of waste generation of these countries including Tanzania; has been increasing yearly with unchanging methods of waste disposal. This increase of municipal solid waste generated necessitates municipals to improve the method of waste disposal and handling [3]. Waste disposal method with improper safety conditions and regulations can cause environmental problems $[4,5]$. Common method of waste disposal in most of developing countries, especially those in Sub Sahara Africa is dumping, open burning and landfill [6]. The possibilities of recycling waste materials and energy recovery from waste are better methods of waste management system currently used. The utilization of municipal solid waste to energy will assist to mitigate fossil energy use [4].

The municipal solid waste production rate is varying from place to place due to different levels of inhabitant economic and the seasonal or climatic conditions of the year and therefore the net energy content of municipal solid waste of different place also differs from each other [7]. The waste materials are dynamic and different in sizes and shape $[8,9]$. Neither it's physical nor chemical properties of municipal solid waste are the same; the properties are varying seasonal and regional. When compared the properties of fossil fuels or biomass, the properties of municipal solid waste are dynamic. In this way, different type of waste disposal system designs needed to be developed. There are three basic method of waste disposal; these include physical, biological and thermal methods [10]. The physical method of waste disposal, is the method of waste disposal by converting waste to physical forms such as pellets, briquettes or chips for further use in thermal process to acquire energy from waste [11]. Biological methods of waste disposal are the process of waste disposal in which the organic waste recovering by composting or digestion. The results from compost materials can be used as compost manure [12]. The 
emitted gas during the processes such as methane can be tapped and used as fuel for electricity generation, for driving internal combustion engines and heat generator in combine heat and power systems $[7,13]$. Thermal waste treatment is the process of waste disposal that use heat to treat waste materials [1]. The waste management disposal by using thermal method has many challenges $[14,15]$. The incineration, gasification and pyrolysis are amongst the known techniques [16]. The waste disposal by incineration may reduce waste volume by $90 \%$ and weight by $75-80 \%$. [17, 18].

The incineration is the common method of waste disposal in some hospitals in Tanzania, most of these incinerators are locally brick made with poor performance [19]. The utilization of the energy in combine heat and power can be used in boilers for the electricity generation [14]. The interactions that take place within the process including pyrolysis, combustion, heat transfer, mass transfer and gas flow [20].

In order to identify the proper operating procedures of incinerator that should be practiced on municipal solid waste incinerators, the study of flue gas emission associated with incinerator operating conditions is necessary. The incinerator can become a big polluter if not properly operated [9]. The flue gas from incinerator contain particles and gases which are harmful and toxic to human and environment [21]. If the mixing level of the burnt wastes are better operated, the amount of pollutants to the environment will be reduced [22]. The emission gases from incinerator indicate the combustion behavior of the incinerator, design, operation and the mixing of waste materials in the combustion chamber [23, 24].

Pollution gases such as $\mathrm{SO}_{\mathrm{X}}, \mathrm{NO}_{\mathrm{X}}$ and $\mathrm{CO}_{2}$ which can be formed during the combustion of municipal solid wastes can dissolve in the atmosphere and form an acid rain [25, 26]. The $\mathrm{NO}_{\mathrm{X}}$ can be produced in large amount when the temperature of combustion exceeds $1100^{\circ} \mathrm{C}$. The concentration of $\mathrm{SO}_{\mathrm{X}}$ courses the formation of $\mathrm{H}_{2} \mathrm{SO}_{4}$, which increases the concentration of $\mathrm{H}+$ ion and therefore makes the rain water drops to be harmful to human and environment [27]. When rain water is too acidic, it can cause problem such as killing fish in water, damage crops [28, 29], erode buildings and roads [27, 30].

The aim of this study is therefore, to analyze the flue gas emission from an existing incinerator for the purpose of studying the operating conditions of the existing design in order to improve incinerator design and operating condition.

\section{Materials and Methods}

\subsection{Materials}

\subsubsection{Waste Sample Composition}

The municipal solid wastes were collected from Bagamoyo municipality dump located at Sanzale. The waste sample composition is studied and taken from the average composition ratio of the municipal solid waste studied from previous works reported by [11,31-34]. This composition will be taken as a standard for the current work. The wastes were sorted to separate the combustible and non-combustible wastes to conform to standardize ASTM D5231-92 [35]. The waste mass of about $150 \mathrm{~kg}$ from dump were packed in polythine bags of about $50 \mathrm{~kg}$ each and then transported to the incinerator ready for incineration. Diesel is used as auxiliary fuel to run the burners.

\subsubsection{Waste Sample Formula for Reactions}

The samples formula of municipal solid waste used for this experiment were adopted from ultimate and proximate analysis results found in Arusha, Tanzania [36].

\subsubsection{Prototype Incinerator Design}

The pilot incinerator for this study was the fixed bed incinerator located at Bagamoyo hospital, Figure 1, 2 and 3

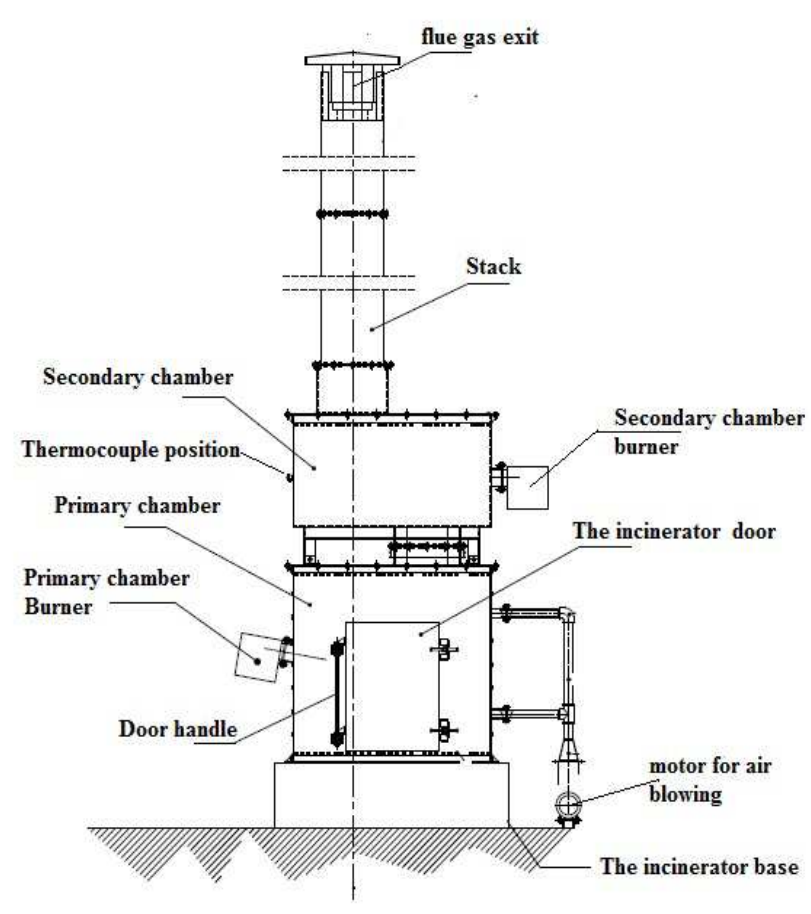

Figure 1. The incinerator layout at Bagamoyo.

\subsection{Working Principles of the Incinerator}

\subsubsection{Background}

This is the starved air incinerator; it composes of two combustion chambers with batch type feeding as shown in Figure 1. The two chambers have two different functions. The primary (ignition) chamber is to ignite the waste and secondary (combustion) chamber is for combustion. The operating temperature for primary chamber can be varied between 400 and $500^{\circ} \mathrm{C}$ by adjusting the fuel supply to the burner while the secondary chamber temperature can vary from 800 to $1000^{\circ} \mathrm{C}$. The primary chamber maintains minimum temperature sufficient to sustain combustion and killing microorganism in the waste. The minimum temperature need to prevent refractory damage and minimum generation of volatiles to the secondary chamber. This is because high temperatures at primary chamber causes vigorous burning and also cause solid metal to evaporate and 
enter the secondary chamber as vapor which will increase the particulate matters to the flue gases. The high temperature at primary chamber can affect the combustion gas volume and rapid increase in flue gas volume at secondary chamber.

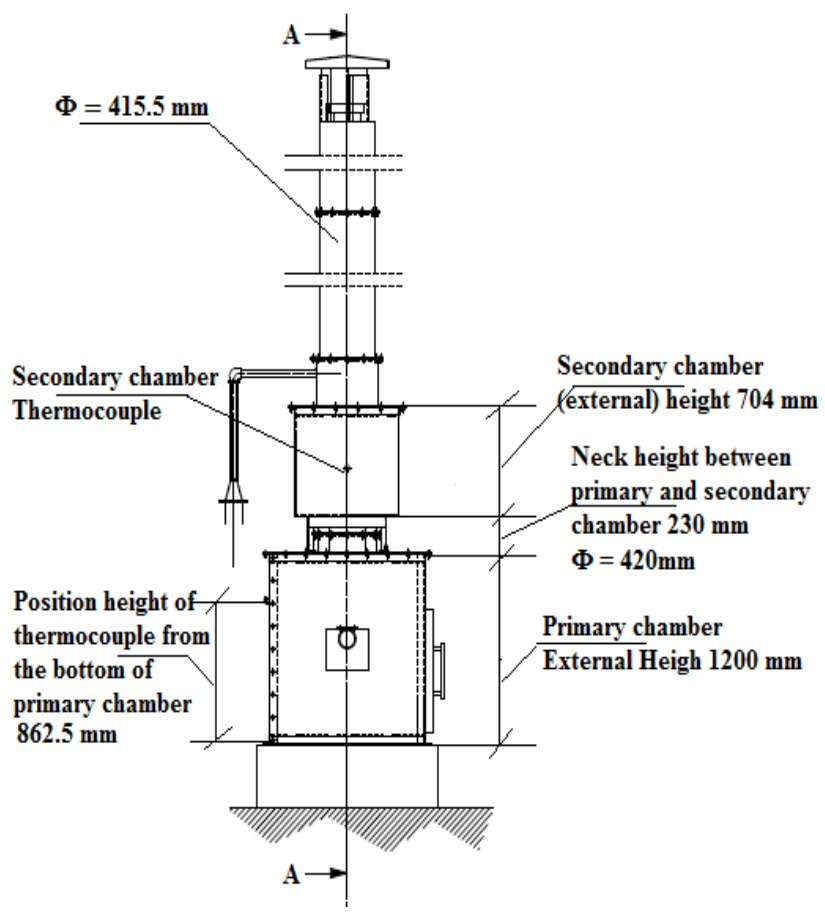

Figure 2. The incinerator layout side view.

This incinerator is not included an air control device because it is believed that with proper combustion control through proper and precise operation, the system can meet the emission regulations. The Chinese standards of emission regulations for pollution for power plants shown in Table 1

Table 1. Emission standards for waste to energy power plant.

\begin{tabular}{llll}
\hline Standard & Item & Threshold limit value & Unit \\
\hline GB 13233-2003 & $\mathrm{SO}_{2}$ & 400 & $\mathrm{ppm}$ \\
& $\mathrm{NO}_{\mathrm{X}}$ & 450 & $\mathrm{ppm}$ \\
GB 13233-2011 & $\mathrm{SO}_{2}$ & 100 & $\mathrm{ppm}$ \\
& $\mathrm{NO}_{\mathrm{X}}$ & 100 & $\mathrm{ppm}$ \\
\hline
\end{tabular}

Source: [37]

\subsubsection{Operating Procedure}

The first thing is to remove the ash which was left from the last cycle. The ash has been cooled down for more than 8 hours overnight. Second is charging the waste to the incinerator. This is done manually. At this stage the thing to consider is the heating value of waste materials and moisture contents.

These affect the performance of an incinerator. The high moisture contents will provide insufficient thermal input and need excessive fuel consumption while the higher heating value waste may exceed thermal capacity of the incinerator.

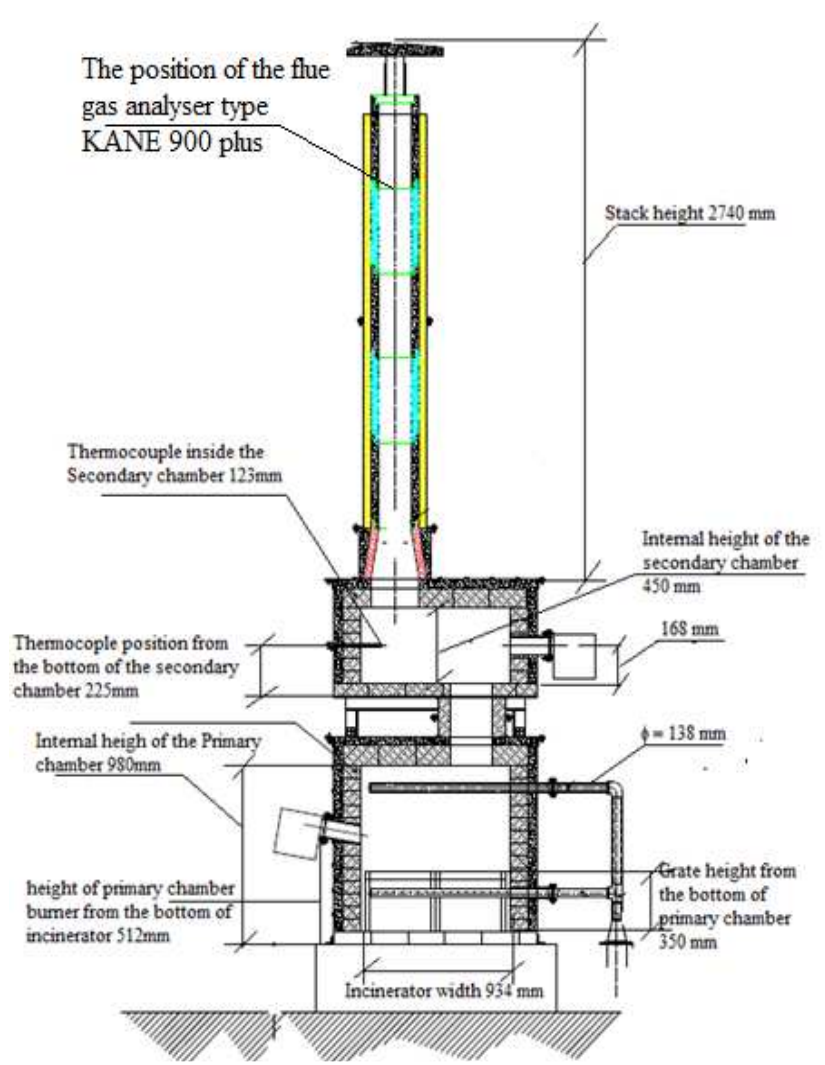

Figure 3. The incinerator layout A-A cross section view.

Prior ignition of waste, the secondary chamber is pre heated to a predetermined temperature of $400^{\circ} \mathrm{C}$ by the secondary burner. The combustion process in the primary chamber is controlled to obtain starved air supply. The starved air supply causes the incomplete combustion products. The incomplete combustion products formed are the pyrolysis gases which will burn again in the secondary chamber to complete the combustion. The air blowers are installed on the side of the incinerator for supply air to secondary and primary chambers as shown in Figure 1. The two thermocouples type $\mathrm{K}$ are installed in the combustion chamber near the exit point in order to read the representative temperature of each chamber shown in Figure 2

The outlet of secondary chamber is supplied with excess air to ensure the complete combustion (Figure 3) while the primary chamber is supplied by starved air to pyrolysed the waste. The burners are installed within the combustion chambers to ignite the waste and to maintain the combustion temperature shown in Figure 3.

The flue gas measurements are taken from the stack using Hand-held combustion analyzer type Kane 900 plus placed at $300 \mathrm{~mm}$ below the exit of the stack and $150 \mathrm{~mm}$ inside the stack. The flue gas analyzed including $\mathrm{CO}, \mathrm{CO}_{2}, \mathrm{NO}_{\mathrm{X}}$ and $\mathrm{SO}_{2}$ After the complete incineration process the incineration is switched off for cooling.

\subsection{Methods}

2.3.1. The Operating Incinerator under Normal Conditions. The running of incinerator was done parallel with the 
emission measurements of flue gas from the incinerator at the stack shown in Figure 3.Emission gases and temperature results from the incinerator under no load and with load were tabulated and recorded. The operation of the incinerator was set with load of $50 \mathrm{kgs}$ with variation temperatures of primary and secondary chambers. The temperatures were in the range of $400{ }^{\circ} \mathrm{C}$ against 800,900 and $1000{ }^{\circ} \mathrm{C}$ and $500^{\circ} \mathrm{C}$ against 800,900 , and $1000^{\circ} \mathrm{C}$ for primary and secondary chambers respectively. The flue gas emission released during the incineration process and the ash left out after the completing the incineration were recorded.

\subsubsection{The flue Gas Analysis with Variation of Primary Chamber Temperature}

The flue gas emissions were recorded by varying the primary chamber temperature for analyzing the performance of the incinerator. The primary chamber temperature is set to $400{ }^{\circ} \mathrm{C}$ and $500{ }^{\circ} \mathrm{C}$ The flue gas emission readings were recorded. The combustion products gases $\mathrm{O}_{2}, \mathrm{CO}_{2}, \mathrm{CO}$ and $\mathrm{NO}_{\mathrm{X}}$ are recorded and plotted.

The efficiency of incinerator was also analyzed by using
$\mathrm{CO}_{2}$ an indicator, in this way a ratio in equation (1) was utilized

$$
\frac{\mathrm{CO}_{2}}{\mathrm{CO}_{2}+\mathrm{CO}} \times 100 \%
$$

Where:

$\mathrm{CO}_{2}$ - concentration of Carbon dioxide

$\mathrm{CO}$ - concentration of Carbon monoxide

The results were tabulated in Table 4 and 5 and plotted in Figure 6 and 7.

\section{Results and Discussion.}

\subsection{The Waste Sample Composition.}

The average value of waste samples composition from [11, 31-34] were tabulated in Table 2(a). These were used as the standard composition for this experiment.

Table 2(a). Waste sample composition of Municipal solid waste.

\begin{tabular}{|c|c|c|c|c|c|c|}
\hline \multirow{3}{*}{ Country } & \multicolumn{5}{|c|}{ Composition } & \multirow{3}{*}{ Source } \\
\hline & \multicolumn{4}{|c|}{ Combustible } & \multirow{2}{*}{$\begin{array}{c}\text { Non } \\
\text { combustibles }\end{array}$} & \\
\hline & Plastics & Papers & organic waste & Textiles & & \\
\hline Tanzania & 7 & 11 & 67 & 2 & 13 & [11] \\
\hline Kenya & 13.8 & 11.3 & 58.8 & 7.8 & 8.3 & [31] \\
\hline Nigeria & 10 & 6 & 47 & 7 & 30 & {$[32]$} \\
\hline Ghana & 3.3 & 6.6 & 73 & 2.2 & 14.9 & [33] \\
\hline Zambia & 5 & 5 & 50 & - & 40 & [34] \\
\hline Ethiopia & 2 & 4 & 88 & - & 6 & [34] \\
\hline Average values (\%) & 6.0 & 6.7 & 66.0 & 4.8 & 18.6 & \\
\hline
\end{tabular}

Table 2(b). The combustibles fraction of Municipal solid waste

\begin{tabular}{cccccc}
\hline Combustible wastes & Plastics & Papers & Food and organic & Textiles \\
\hline$(\%)$ & 7 & 8 & 82 & 3 \\
\hline
\end{tabular}

The sample obtained shows that the composition of municipal solid waste has about $81.4 \%$ of combustible waste and $18.6 \%$ of non-combustible waste as shown in Table 2(a). These values are also found by in [38] in his research in Mirpurkhas city in Pakistan, where he revealed that the 60 $70 \%$ of total waste generated from municipal solid waste is combustible.

The combustible waste fraction has the average of $82 \%$ of food and organic waste, $8 \%$ of paper waste, $7 \%$ of plastics and $3 \%$ of textiles. This gives the fraction of combustible waste $93 \%$ biodegradable and $7 \%$ non-biodegradable wastes as shown in Table 2(b).

This suggest that the energy from municipal solid waste can be recovered by either using biogenic method or by using thermal treatment method. Textiles and paper wastes are easily combusted because it composed of lignocelulosic biomass. The food and organic waste contains more than $60 \%$ of lignocelulosic biomass [39]. Lignocelulosic biomass are poor and slow in hydrolysis rates and low cellulose digestibility
[40]. Compared to non cellulosic biomass, cellulosic materials are not efficiently disrupt orderly hydrogen bonds among them and therefore slow down hydrolysis rates [40].The cellulose in biomass consists of unorganized crystaline structure, amorphous structure bundled together to form cellulose fibrils. Owing to the location of these cellulose within the cell walls, the accessibility of enzymes are restricted and interfered [39]. The presence of lignin from the food and organic waste fraction of municipal solid waste, cause the waste impermeable and resistance against microbial, thus make degradation of waste by microbial very tough [41]. The incineration is better option and faster energy recovery method than biogenic methods [42].

\subsection{Empirical Formula for Waste Sample Formulation}

For development of empirical formula for municipal solid waste, the ultimate analysis results were used. The values are tabulated in table 3 . 
Table 3. Proximate and ultimate analysis of Arusha municipal solid waste.

\begin{tabular}{|c|c|c|c|c|c|c|c|}
\hline \multirow[b]{2}{*}{ Location } & \multicolumn{7}{|c|}{ Proximate analysis } \\
\hline & \multicolumn{2}{|l|}{$\begin{array}{c}\text { MC as received } \\
\text { (wt.\%) }\end{array}$} & $\begin{array}{c}\text { VM } \\
\text { (wt.\%)DB }\end{array}$ & $\begin{array}{c}\text { Ash } \\
\text { (wt.\%)DB }\end{array}$ & \multicolumn{2}{|l|}{$\begin{array}{c}\text { FC } \\
\text { (wt.\%) DB }\end{array}$} & $\begin{array}{c}\text { HHV } \\
(\mathrm{MJ} / \mathrm{kg})\end{array}$ \\
\hline Kaloleni & 59.67 & & 74.43 & 8.16 & 17.41 & & 11.90 \\
\hline Sakina & 63.99 & & 84.00 & 10.00 & 6.00 & & 11.37 \\
\hline Central market & 55.70 & & 78.30 & 13.48 & 8.22 & & 12.76 \\
\hline \multirow[t]{2}{*}{ Average } & 59.79 & & 78.91 & 10.55 & 10.54 & & 12.01 \\
\hline & \multicolumn{7}{|c|}{ Ultimate analysis } \\
\hline Location & $\mathrm{C}$ & $\mathrm{H}$ & $\mathrm{O}$ & $\mathrm{N}$ & $\mathrm{S}$ & $\mathrm{Cl}$ & $P$ \\
\hline Kaloleni & 55.57 & 5.34 & 34.88 & 2.09 & 0.31 & 0.04 & 0.10 \\
\hline Sakina & 55.70 & 5.29 & 34.27 & 2.13 & 0.22 & 0.07 & 0.13 \\
\hline Central market & 53.20 & 5.24 & 34.71 & 2.86 & 0.37 & 0.04 & 0.11 \\
\hline Average & 54.82 & 5.29 & 34.62 & 2.36 & 0.30 & 0.05 & 0.11 \\
\hline Normalize to $100 \%$ & 56.20 & 5.42 & 35.49 & 2.42 & 0.31 & 0.05 & 0.11 \\
\hline \multirow{2}{*}{$\begin{array}{l}\text { Calculate number of } \\
\text { moles }\end{array}$} & $x_{C}$ & $x_{H}$ & $x_{o}$ & $x_{N}$ & $x_{s}$ & $x_{c l}$ & $x_{p}$ \\
\hline & $m_{C}$ & $m_{H}$ & $m_{o}$ & $m_{N}$ & $m_{s}$ & $m_{c l}$ & $m_{p}$ \\
\hline \multirow{3}{*}{$\begin{array}{l}\text { Number of moles in } \\
100 \mathrm{kgs}\end{array}$} & 56.20 & 5.42 & 35.49 & 2.42 & 0.31 & 0.05 & 0.11 \\
\hline & 12 & 1 & 16 & 14 & 32 & 32 & 28 \\
\hline & 4.683 & 5.423 & 2.218 & 0.173 & 0.010 & 0.001 & 0.004 \\
\hline
\end{tabular}

Source:[43]

Where: MC - Percentage of moisture in municipal solid waste

VM - Volatiles matter

FC - Fixed Carbon

$x_{C}, x_{H}, x_{O}, x_{N}, x_{S}, x_{C l}, x_{P}$ are the fraction composition of Carbon, Hydrogen, Oxygen, Nitrogen, Sulphur, Chlorine and phosphorus respectively.

$m_{C}, m_{H}, m_{O}, m_{N}, m_{S}, m_{C l}, m_{P}$ are the Atomic number of the Carbon, Hydrogen, Oxygen, Nitrogen, Sulphur, Chlorine and phosphorus respectively.

The chemical formula for municipal solid waste for our case will be

$$
\mathrm{C}_{4.683} \mathrm{H}_{5.423} \mathrm{O}_{2.218} \mathrm{~N}_{0.173} \mathrm{~S}_{0.010} \mathrm{Cl}_{0.001} P_{0.004}
$$

- The empirical formula of a chemical compound is a simple expression of the relative number of each type of atom in it. It shows the proper ratio of atom in the compound.

- It can help in predicting chemical reactions which will assist in predicting the output result of reaction.

\subsection{The Operations of an Incinerator under Normal Conditions}

The incinerator operates as normal, the variation of temperature in primary and secondary chambers with the flue gas emission were tabulated in Table 4 and plot in the Figure 4, Figure 5 and Figure 6.
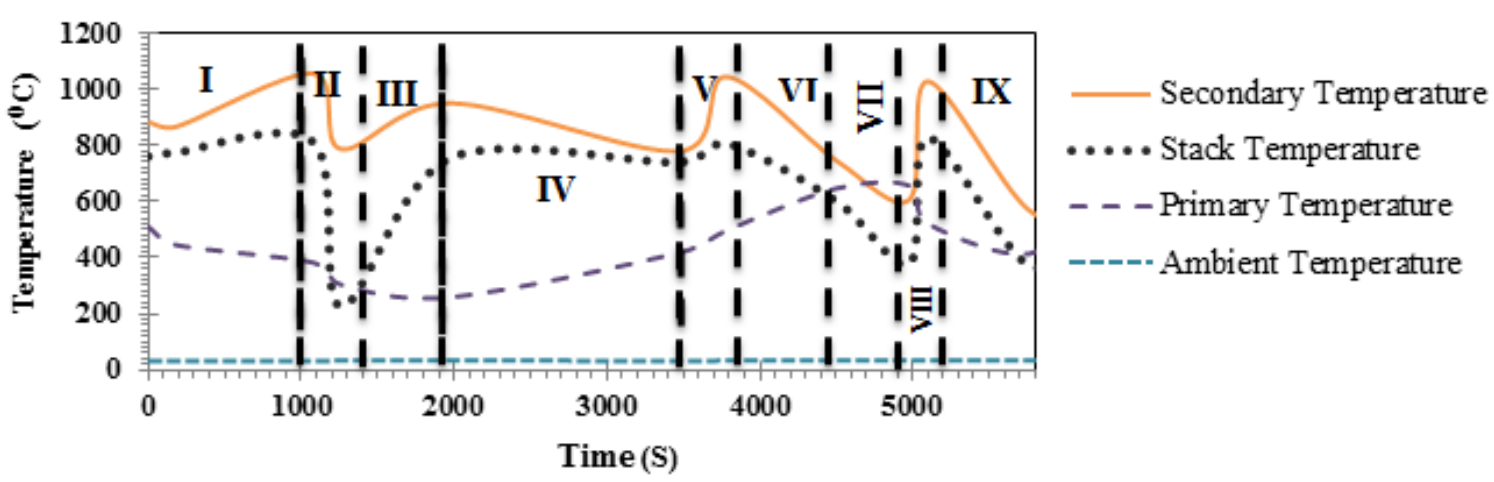

Figure 4. Typical temperature distribution in an incinerator for one complete cycle.

Table 4. The operation for one cycle with emission from incinerator.

\begin{tabular}{|c|c|c|c|c|c|c|c|c|c|}
\hline \multirow{3}{*}{$\begin{array}{l}\text { Time } \\
\text { sec }\end{array}$} & \multicolumn{6}{|c|}{ Emissions } & \multicolumn{2}{|c|}{ Temperature } & \multirow{3}{*}{ The comments on the operating conditions } \\
\hline & $\mathbf{O}_{2}$ & $\mathrm{CO}$ & $\mathrm{CO}_{2}$ & $\mathbf{T}_{\mathrm{S}}$ & $\mathbf{T}_{\mathrm{Amb}}$ & $\mathbf{N O}_{\mathbf{x}}$ & $\mathbf{T}_{\mathbf{P r i}}$ & $\mathbf{T}_{\text {Sec }}$ & \\
\hline & $\%$ & ppm & $\%$ & ${ }^{\circ} \mathrm{C}$ & ${ }^{\circ} \mathrm{C}$ & ppm & ${ }^{\circ} \mathrm{C}$ & ${ }^{\circ} \mathrm{C}$ & \\
\hline 0 & 5.5 & 101 & 11.4 & 760.3 & 30.9 & 71.3 & 509.3 & 883.3 & Without Load \\
\hline 180 & 3.9 & 5832 & 12.6 & 774 & 31.5 & 2374 & 445 & 865.7 & At start after feeding \\
\hline 1080 & 8.3 & 12 & 9.3 & 811 & 31.7 & 165 & 382 & 1054.3 & Mid of incineration (Sec burner On) \\
\hline 1260 & 19.6 & 317 & 1 & 225.7 & 32.3 & 199 & 303.3 & 786.7 & Sec. Burner OFF \\
\hline 1980 & 8.9 & 0 & 8.9 & 755.3 & 32.3 & 92 & 259 & 949.7 & Sec. Burner ON, Near end \\
\hline
\end{tabular}




\begin{tabular}{|c|c|c|c|c|c|c|c|c|c|}
\hline \multirow{3}{*}{$\begin{array}{l}\text { Time } \\
\text { sec }\end{array}$} & \multicolumn{6}{|c|}{ Emissions } & \multicolumn{2}{|c|}{ Temperature } & \multirow{3}{*}{ The comments on the operating conditions } \\
\hline & $\mathbf{O}_{2}$ & $\mathrm{CO}$ & $\mathrm{CO}_{2}$ & $\mathbf{T}_{\mathrm{S}}$ & $\mathbf{T}_{\text {Amb }}$ & NO $_{x}$ & $\mathbf{T}_{\text {Pri }}$ & $\mathbf{T}_{\text {Sec }}$ & \\
\hline & $\%$ & ppm & $\%$ & ${ }^{\circ} \mathrm{C}$ & ${ }^{\circ} \mathrm{C}$ & ppm & ${ }^{\circ} \mathrm{C}$ & ${ }^{\circ} \mathrm{C}$ & \\
\hline 3780 & 7.8 & 0 & 9.63 & 807.7 & 32.4 & 67 & 496.3 & 1044 & $500 / 1000$ \\
\hline 4500 & 6.9 & 1159 & 10.4 & 600.7 & 32.9 & 582 & 646 & 745.7 & Door open slightly and burner off \\
\hline 4980 & 16 & 716.3 & 3.6 & 377.3 & 33.1 & 302.3 & 655.7 & 606.7 & Burners off \\
\hline 5100 & 8.2 & 0 & 9.4 & 828 & 33.3 & 87 & 520.7 & 1027.7 & Sec Burner on/Initial stage \\
\hline 5760 & 17.6 & 162 & 2.4 & 371.7 & 33.7 & 99 & 413.3 & 569 & End of incineration (Sec burner off) \\
\hline
\end{tabular}

Where:

$\mathrm{O}_{2}$ Mass of oxygen to the total mass of the flue gas in percentage $(\%)$

CO Mass of carbon monoxide to the total mass of the flue gas in parts per millions (ppm)

$\mathrm{CO}_{2}$ Mass of carbon dioxide to the total mass of the flue gas in percentage $(\%)$
$\mathrm{NO}_{\mathrm{x}}$ Mass of Nitrogen oxides to the total mass of the flue gas in parts per millions (ppm)

$\mathrm{T}_{\mathrm{s}}$ Temperature of the stack $\left({ }^{\circ} \mathrm{C}\right)$

$\mathrm{T}_{\text {pri. }}$ Primary chamber temperature of an incinerator $\left({ }^{\circ} \mathrm{C}\right)$

$\mathrm{T}_{\text {sec }}$ Secondary chamber temperature of an incinerator $\left({ }^{\circ} \mathrm{C}\right)$

$\mathrm{T}_{\text {amb }}$ Ambient temperature $\left({ }^{\circ} \mathrm{C}\right)$

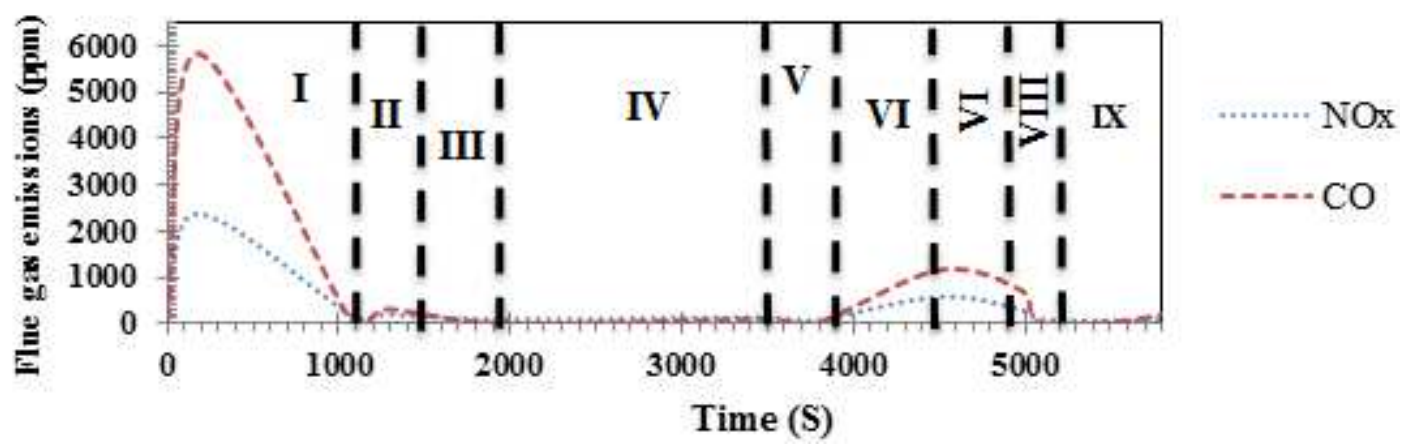

Figure 5. $\mathrm{NO}_{X}$ and $\mathrm{CO}$ emissions from incinerator for one complete cycle

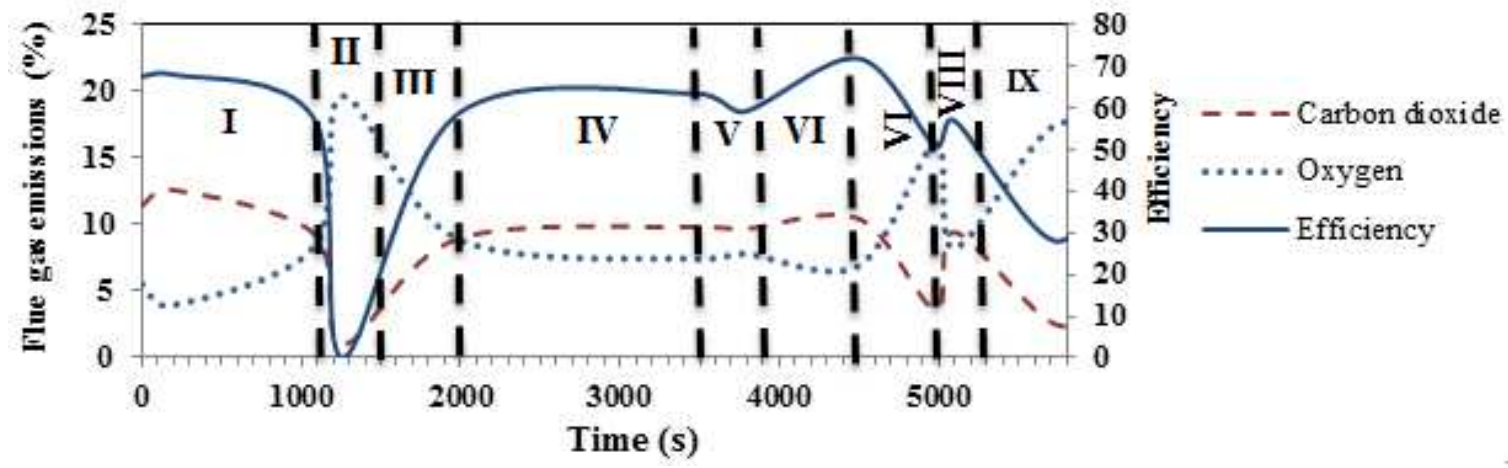

Figure 6. Efficiency, $\mathrm{CO}_{2}$ and $\mathrm{O}_{2}$ emission from incinerator.

The measurement and results observed from an incinerator are divided into regions. There are 9 regions division. Region I show that when the incinerator working under no load, the maximum combustion temperature attained for the stack was $1073 \mathrm{~K}$ as shown in Figure 4. The emission of $\mathrm{NO}_{\mathrm{X}}$ and $\mathrm{CO}$ seems to be much higher at the beginning and then suddenly decreases. This is due to the incomplete combustion of the fuel at starting shown in Figure 5. The $\mathrm{NO}_{\mathrm{X}}$ formed in this case is prompt $\mathrm{NO}_{\mathrm{X}}$ which normally coming from the combustion of Nitrogen bearing fuels. The fuel released nitrogen bound in them as free radical which are oxidized to $\mathrm{NO}_{\mathrm{X}}[44]$.

At the second region the temperature of the incinerator falls. The stack temperature decreases to $520 \mathrm{~K}$. The primary chamber temperature decreases to $576 \mathrm{~K}$ while secondary temperature falls to $556 \mathrm{~K}$, this is because at this time the incinerator burners are switched off and the feeding stock is added to the incinerator. The incinerator efficiency also falls to zero since there is no combustion during the feedstock and all the burners are switched off.

At region III, all the burners are switched on. The temperature of the incinerator changes, the secondary and stack temperature rises while the primary temperature falls. The cause of primary chamber temperature to fall is due to the feedstock temperature which is at room temperature from the dump. The emissions show that the $\mathrm{CO}_{2}$ concentration increases while the $\mathrm{O}_{2}$ concentration decreases as shown in Figure 6. The concentration of carbon monoxide decreases while $\mathrm{NO}_{\mathrm{X}}$ emissions become constant at $92 \mathrm{ppm}$, Figure 5. 
At region IV the temperature of the primary chamber increases while that of secondary slightly decreases, this showing that the feed stock is already acquired the uniform temperature with the combustion chamber. The emission of $\mathrm{NO}_{\mathrm{X}}$ and $\mathrm{CO}$ is at constant of about 136 and $100.7 \mathrm{ppm}$ Figure 5 while the $\mathrm{O}_{2}$ and $\mathrm{CO}_{2}$ emission are about 7.4 and $9.8 \%$ respectively. The efficiency of the incinerator combustion fluctuates between 63 and $59 \%$ as shown in Figure 6. The decrease in secondary chamber temperature is caused by reduction of incomplete combustion gases which are expected from primary chamber to the secondary chamber such as $\mathrm{CO}$ which decreases from 136 to 100.7 ppm shown Figure 5 [45].

At region $\mathrm{V}$, the incinerator temperature of all chambers increases Figure 4. The combustion efficiency is slightly decreases Figure 6. The concentration of $\mathrm{NO}_{\mathrm{X}}$ and $\mathrm{CO}$ is slightly decreases. The $\mathrm{NO}_{\mathrm{X}}$ concentration decreases from 136 ppm to $67 \mathrm{ppm}$ while concentration of $\mathrm{CO}$ decreases from 100.7 to $0 \mathrm{ppm}$ (Figure 5). The decrease of $\mathrm{NO}_{\mathrm{X}}$ and $\mathrm{CO}$ and the efficiency of the combustion are caused by switching off the second burner for trying to maintain the desired temperature. The $\mathrm{NO}_{\mathrm{X}}$ concentration decreased because the amount of diesel of combustion decrease as the burner is switched off. The only $\mathrm{NO}_{\mathrm{X}}$ formed at this temperature is a prompt $\mathrm{NO}_{\mathrm{X}}[44]$ which is normally comes from the fuel used.

At region VI, the burner is switch on again to maintain the desired temperature. The temperature of secondary chamber and stack decreases while the temperature of the primary chamber increases. The emission shows that there is increase in $\mathrm{CO}$ and $\mathrm{NO}_{\mathrm{X}}$ concentration. The $\mathrm{CO}$ increases from 0 to $1159.3 \mathrm{ppm}$ and that of $\mathrm{NO}_{\mathrm{X}}$ increase from 67 to $582 \mathrm{ppm}$ (Figure 5). The efficiency of combustion is also increased from $59 \%$ to $71.7 \%$ (Figure 6 ). This is the highest efficiency of this incinerator in which the concentration of $\mathrm{O}_{2}$ is $6.9 \%$ and that of $\mathrm{CO}_{2}$ is $10.4 \%$. These value approaches the recommended value of $\mathrm{O}_{2}$ at the exit point which was studied in simulation of fixed bed thermal oxidizer for solid waste disposal. The value obtained and recommended for oxygen at exit point is $6 \%$ [46].

At region VII, the incinerator door is slightly opened to increase the excess air supply and the primary chamber burner is switched off. The secondary and stack temperature are decreasing while the primary temperature is still increasing (Figure 4). This may be caused by complete combustion in the primary chamber by supplying excess air by opening the door and therefore decrease the incomplete combustion gases in the secondary chamber. The $\mathrm{NO}_{\mathrm{X}}$ and $\mathrm{CO}$ is decreases from 582 to $302.3 \mathrm{ppm}$ and from 1159.3 to $716.3 \mathrm{ppm}$ respectively (Figure 5). The efficiency also is decreased from 71.7 to $50.7 \%$ (Figure 6).

At the region VIII, the secondary burner is switched on for about 100 s while the primary chamber burner is still off. This is done in order to maintain the required temperature. The secondary and stack temperature rise rapidly (Figure 4). The efficiency is slightly increased to $56 \%$ and then raised and fluctuate to $50 \%$ (Figure 6)

At region IX, all the temperature decreases. The efficiency fall to $27 \%$ and $\mathrm{CO}_{2}$ concentration decreased to $6 \%$ while $\mathrm{O}_{2}$ increases to $20.1 \%$ (Figure 6 ). The cause of temperature rise from secondary chamber is due to the high concentration of incomplete combustion gases at the chamber. These gases were combusted by the burner and suddenly they diminished.

\subsection{Flue Gas Analysis with Variation of Primary and Secondary Chambers Temperatures}

\subsubsection{Analysis of $\mathrm{O}_{2}, \mathrm{CO}_{2}, \mathrm{CO}$ and $\mathrm{NO}_{x}$ at Primary Chamber Temperature Fixed at $400^{\circ} \mathrm{C}$}

Table 5. Flue gas emission at primary temperature $400^{\circ} \mathrm{C}$.

\begin{tabular}{|c|c|c|c|c|c|}
\hline Primary Temp ${ }^{\circ} \mathrm{C}$ & Secondary $\operatorname{Temp}^{\circ} \mathrm{C}$ & $\mathrm{O}_{2}(\%)$ & CO (ppm) & $\mathrm{CO}_{2}(\%)$ & $\mathrm{NO}_{\mathrm{X}}(\mathrm{ppm})$ \\
\hline \multirow{4}{*}{400} & 808.00 & 8.76 & 209.20 & 9.16 & 204.00 \\
\hline & 902.00 & 11.96 & 47.20 & 5.66 & 92.00 \\
\hline & 1005.00 & 11.70 & 3.20 & 4.20 & 51.00 \\
\hline & 1069.00 & 12.20 & 0.60 & 4.26 & 57.60 \\
\hline
\end{tabular}

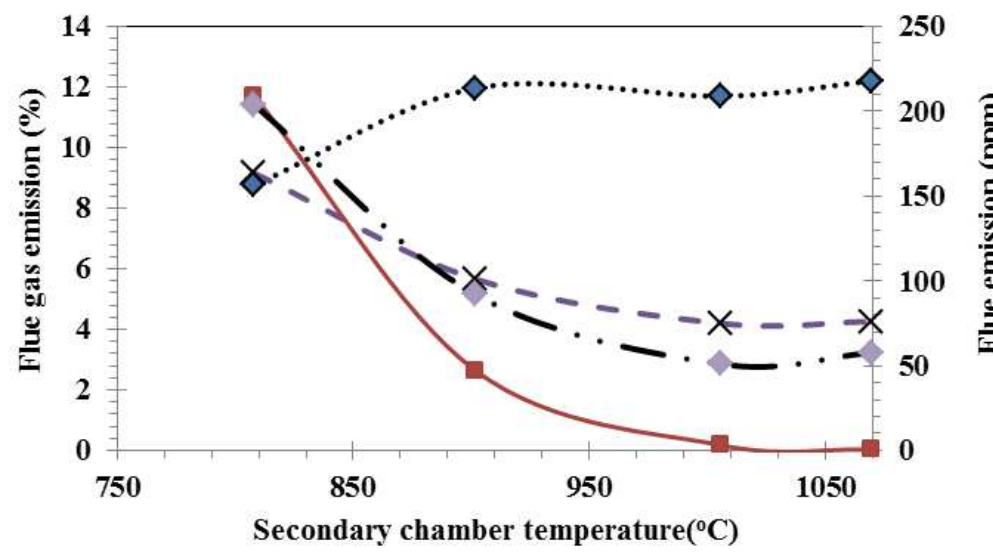

$\cdots \diamond . .02(\%)$

$-\leftarrow \mathrm{CO} 2(\%)$

$\longrightarrow-\operatorname{CO}(\mathrm{ppm})$

$\longrightarrow$ NOx (ppm)

Figure 7: Flue gas emission at primary chamber temperature $400^{\circ} \mathrm{C}$ 


\subsubsection{Analysis of $\mathrm{O}_{2}, \mathrm{CO}_{2}, \mathrm{CO}$ and $\mathrm{NO}_{X}$ at Primary Chamber Temperature Fixed at $500^{\circ} \mathrm{C}$}

Table 6. Flue gas emission at primary temperature $500^{\circ} \mathrm{C}$.

\begin{tabular}{llllll}
\hline Primary Temp. ${ }^{\circ} \mathbf{C}$ & Sec. Temp. $^{~}{ }^{\mathbf{C}}$ & $\mathbf{O}_{2}(\mathbf{\%})$ & $\mathbf{C O}_{(\mathbf{p p m})}$ & $\mathbf{C O}_{2}(\mathbf{\%})$ & NOx $(\mathbf{p p m})$ \\
\hline & 810.30 & 17.24 & 301.80 & 1.84 & 184.20 \\
& 913.70 & 17.32 & 250.40 & 1.80 & 156.60 \\
500 & 1055.30 & 8.64 & 64.40 & 6.06 & 351.80 \\
& 1088.00 & 12.26 & 0.00 & 4.06 & 47.00 \\
& 1093.70 & 10.64 & 0.80 & 4.96 & 168.20 \\
& 1102.70 & 12.26 & 0.00 & 3.70 & 155.80 \\
\hline
\end{tabular}

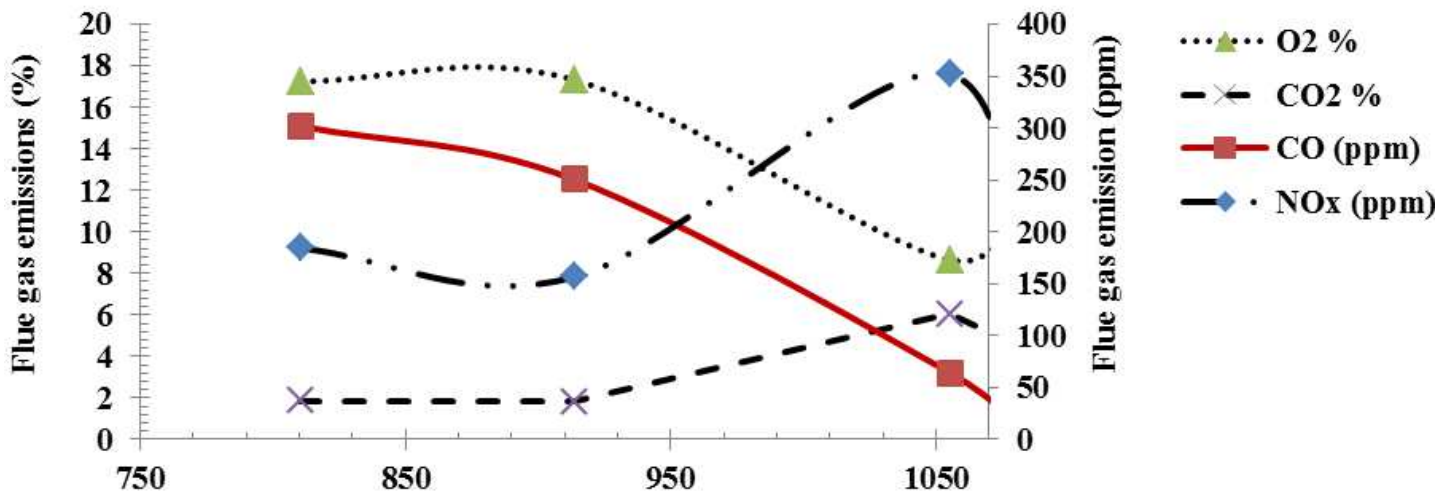

Secondary chamber temperature $\left({ }^{\circ} \mathrm{C}\right)$

Figure 8. Flue gas emission at primary chamber temperature fixed $500^{\circ} \mathrm{C}$.

The flue gas shows that the relation between $\mathrm{O}_{2}$ and $\mathrm{CO}_{2}$ that, as the amount of $\mathrm{CO}_{2}$ is increased the amount of $\mathrm{O}_{2}$ decreases. This indicates that at this point the efficiency of combustion is better

\subsubsection{Analysis of Efficiency, Excess Air and $\mathrm{O}_{2}$ in Flue Gas}

Table 7. The stack temperature against excess air and efficiency of incinerator with primary chamber temperature $400^{\circ} \mathrm{C}$.

\begin{tabular}{|c|c|c|c|c|c|c|c|}
\hline $\mathbf{T}_{\text {Pri/ sec. }}{ }^{o} \mathrm{C}$ & $\mathbf{T}_{\text {Sec }}{ }^{o} C$ & $\mathrm{O}_{2}(\%)$ & $\eta(\%)$ & $\mathrm{CO}_{2}(\%)$ & $\mathbf{T}_{\text {Stack }}{ }^{o} \mathrm{C}$ & $\mathbf{T}_{\text {Amb. }}{ }^{o} C$ & $X_{\text {Air }}(\%)$ \\
\hline \multirow{4}{*}{$400 /(800,900,1000,1100)$} & 808.00 & 8.76 & 57.54 & 9.16 & 749.00 & 31.58 & 72.58 \\
\hline & 902.00 & 11.96 & 44.30 & 5.66 & 705.20 & 31.80 & 276.18 \\
\hline & 1005.00 & 11.70 & 39.80 & 4.20 & 679.40 & 32.00 & 151.96 \\
\hline & 1069.00 & 12.20 & 36.08 & 4.26 & 800.80 & 31.90 & 147.56 \\
\hline
\end{tabular}

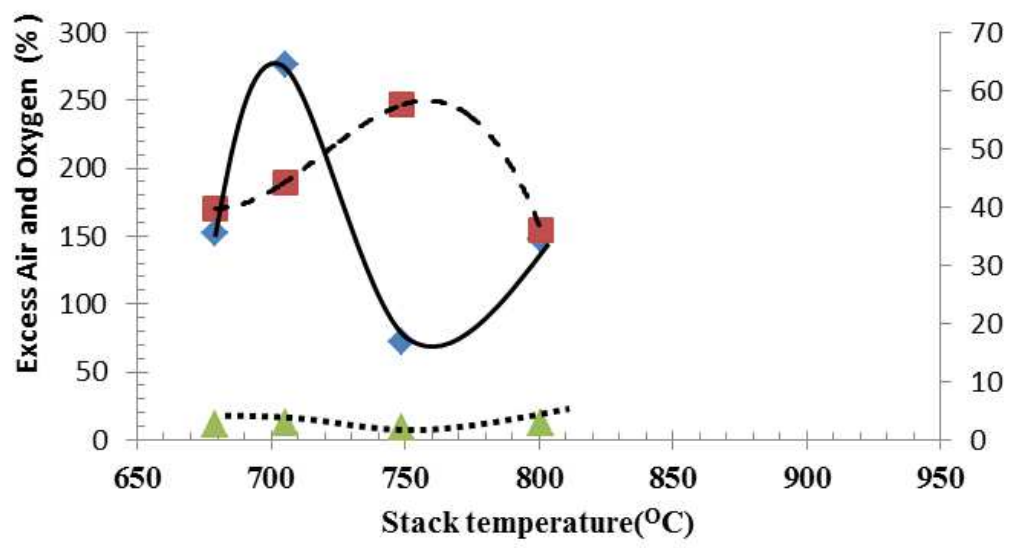

Figure 9. Variation of efficiency against Excess air and oxygen with primary chamber temperature $400^{\circ} \mathrm{C}$. when Primary Chamber Temperature Fixed at $500^{\circ} \mathrm{C}$.

The variation of stack temperature, excess air and the oxygen in the flue gas when changing the primary chamber temperature were analyzed. The results were recorded and tabulated in table 6 and plotted in Figure 7 
The curves shows that when the $\mathrm{O}_{2}$ is about $6.9 \%$ the efficiency is at the highest and when the oxygen is closer to $20 \%$ the efficiency is lowest. This indicates that the combustion is poor when the flue gas composition has much $\mathrm{O}_{2}$ concentration. The excess air also indicates the variation of temperature. As the excess air increases the temperature is decreases and the efficiency is decreases. The efficiency of incinerator seems to increase with increase in temperature.

\subsubsection{Analysis of Efficiency, Excess Air and $O 2$ in Flue Gas when Primary Chamber Temperature Fixed at $500^{\circ} \mathrm{C}$.}

Table 8. The stack temperature against excess air and efficiency of incinerator with primary chamber temperature $500^{\circ} \mathrm{C}$.

\begin{tabular}{|c|c|c|c|c|c|c|}
\hline $\begin{array}{l}\text { Prim/ Sec } \\
\text { Temp. }{ }^{\circ} \mathrm{C}\end{array}$ & $\begin{array}{l}\mathbf{T}_{\text {sec*}} \\
{ }^{0} \mathbf{C}\end{array}$ & $\begin{array}{l}\mathrm{O}_{2} \\
(\%)\end{array}$ & $\begin{array}{l}\eta \\
(\%)\end{array}$ & $\begin{array}{l}\mathbf{T}_{\text {stack }} \\
{ }^{0} \mathrm{C}\end{array}$ & $\begin{array}{l}\mathbf{T}_{\text {Amb }} \\
{ }^{\circ} \mathrm{C}\end{array}$ & $\begin{array}{l}X_{\text {Air }} \\
(\%)\end{array}$ \\
\hline \multirow{6}{*}{$500 /(800,900,1000,1100)$} & 810.30 & 17.24 & 2.78 & 522.60 & 32.40 & 469.60 \\
\hline & 913.70 & 17.32 & 0.00 & 557.40 & 32.30 & 480.50 \\
\hline & 1055.30 & 8.64 & 47.68 & 897.80 & 32.30 & 70.46 \\
\hline & 1088.00 & 12.26 & 26.24 & 893.20 & 33.80 & 214.24 \\
\hline & 1093.70 & 10.64 & 36.96 & 816.00 & 33.80 & 107.40 \\
\hline & 1102.70 & 12.26 & 21.36 & 888.60 & 33.80 & 268.34 \\
\hline
\end{tabular}

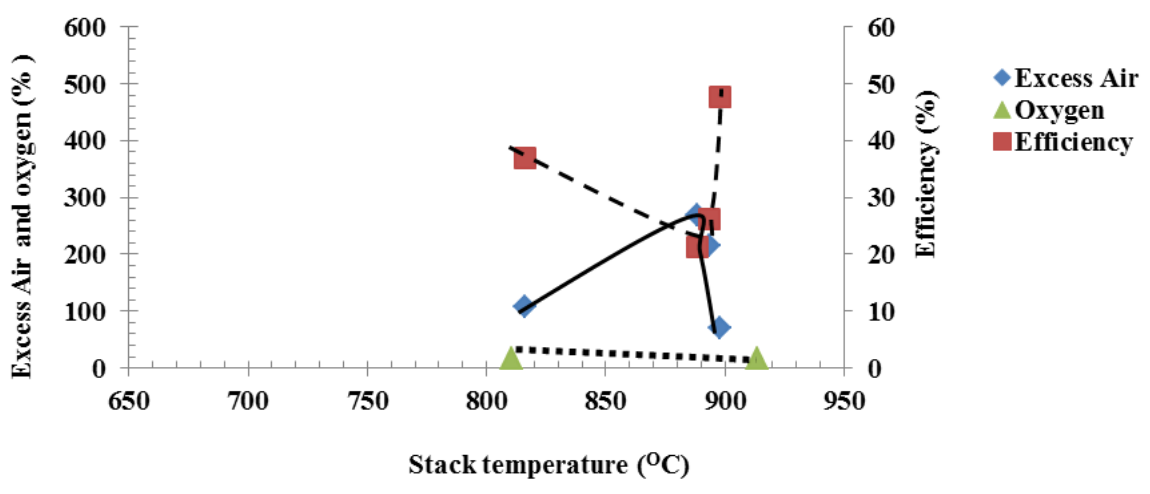

Figure 10. Variation of efficiency against Excess air and oxygen with primary chamber temperature $500^{\circ} \mathrm{C}$.

With primary chamber at $500^{\circ} \mathrm{C}$, the excess air shows to increase at the flue gas composition, as the stack temperature increases, and then it reaches a point when the excess air start to decrease. At this point the $\mathrm{O}_{2}$ concentration at flue gas decreases to about $8 \%$, the efficiency start to increase, the efficiency reach its maximum value when the $\mathrm{O}_{2}$ concentration reaches $6.9 \%$. Showing there is a better combustion at this stage.

\section{Conclusion and Recommendations}

- The waste composition analysis shows that the waste can be used as energy source of as it contains more composition of biodegradable and combustible waste.

- The excess air concentration in the flue gas varies with temperature; it needs to reach a certain point so as to attain the maximum efficiency of the incinerator.

- The incinerator performance is better when the primary chamber set to about $400^{\circ} \mathrm{C}$ and the secondary chamber ranges between $800{ }^{\circ} \mathrm{C}$ and $900{ }^{\circ} \mathrm{C}$

\section{References}

[1] P. T. Williams, Waste treatment and disposal: John Wiley \& Sons, 2005.
[2] M. Hizami, M. Yusoff, and R. Zakaria, "Combustion of Municipal Solid Waste in Fixed Bed Combustor for Energy Recovery," Asian Network for Scientific Information, vol. 12, pp. 1176-1180, 2012.

[3] R. K. Henry, Z. Yongsheng, and D. Jun, "Municipal solid waste management challenges in developing countries-Kenyan case study," Waste management, vol. 26, pp. 92-100, 2006.

[4] M. Rodionov and T. Nakata, "Design of an optimal waste utilization system: a case study in St. Petersburg, Russia," Sustainability, vol. 3, pp. 1486-1509, 2011.

[5] M. Sharholy, K. Ahmad, G. Mahmood, and R. Trivedi, "Municipal solid waste management in Indian cities-A review," Waste management, vol. 28, pp. 459-467, 2008.

[6] S. Rothenberger, C. Zurbrugg, I. Enayetullah, and M. Sinha, Decentralised composting for cities of low and middle income countries: a userïs manual: EAWAG, 2006.

[7] H. Cheng and Y. Hu, "Municipal solid waste (MSW) as a renewable source of energy: Current and future practices in China," Bioresource technology, vol. 101, pp. 3816-3824, 2010.

[8] V. Nasserzadeh, J. Swithenbank, C. Schofield, D. Scott, A. Loader, and A. Leonard, "Design optimization of Coventry municipal solid waste incinerator," Journal of Environmental Engineering, vol. 120, pp. 1615-1629, 1994.

[9] K. A. Arshad, T. Ahmad, and S. Baharun, "Mathematical Modeling Of A Clinical Waste Incineration Process," 2003. 
[10] T. Kaosol, "Sustainable solutions for municipal solid waste management in Thailand," Journal of Civil Engineering and Architecture, vol. 4, pp. 57-65, 2010.

[11] A. Omari, B. Kichonge, G. John, K. Njau, and P. Mtui, "Potential of Municipal Solid Waste, as renewable energy source - a case study of Arusha, Tanzania.," International Journal of Renewable Energy Technology Research, vol. 3, pp. $1-9,2014$.

[12] P. Bundela, S. Gautam, A. Pandey, M. Awasthi, and S. Sarsaiya, "Municipal solid waste management in Indian cities-A review," International Journal of Environmental Sciences, vol. 1, pp. 591-606, 2010.

[13] O. Eriksson, M. Carlsson Reich, B. Frostell, A. Björklund, G. Assefa, J.-O. Sundqvist, et al., "Municipal solid waste management from a systems perspective," Journal of Cleaner Production, vol. 13, pp. 241-252, 2005.

[14] C. Ryu and D. Shin, "Combined heat and power from municipal solid waste: Current status and issues in South Korea," Energies, vol. 6, pp. 45-57, 2012.

[15] D. Shin, S. Choi, J.-E. Oh, and Y.-S. Chang, "Evaluation of polychlorinated dibenzo-p-dioxin/dibenzofuran (PCDD/F) emission in municipal solid waste incinerators," Environmental science \& technology, vol. 33, pp. 2657-2666, 1999.

[16] EA, "Advanced Thermal Treatment of Municipal Solid Waste," E. F. R. Affairs, Ed., ed. London: Defra, 2013.

[17] C. H. Lam, A. W. Ip, J. P. Barford, and G. McKay, "Use of incineration MSW ash: a review," Sustainability, vol. 2, pp. 1943-1968, 2010.

[18] E. Akkaya and A. Demir, "Predicting the heating value of municipal solid waste-based materials: An artificial neural network model," Energy Sources, Part A: Recovery, Utilization, and Environmental Effects, vol. 32, pp. 1777-1783, 2010.

[19] S. Manyele and H. Anicetus, "Management of medical waste in Tanzania hospitals," Tanzania Journal of Health Research, vol. 8, 2006 .

[20] M. Annunziato, I. Bertini, A. Pannicelli, and S. Pizzuti, "Evolutionary Control and On-Line Optimization of an MSWC Energy Process," Journal of Systemics, Cybernetics and Informatics, vol. 4, 2006.

[21] M.-Y. Wey, W.-Y. Ou, Z.-S. Liu, H.-H. Tseng, W.-Y. Yang, and B.-C. Chiang, "Pollutants in incineration flue gas," Journal of hazardous materials, vol. 82, pp. 247-262, 2001.

[22] Y. Yang, M. J. Pijnenborg, M. A. Reuter, and J. Verwoerd, "Modeling the combustion behavior of hazardous waste in a rotary kiln incinerator," Journal of Environmental Science and Health, vol. 40, pp. 1823-1842, 2005.

[23] P. Glarborg, "Hidden interactions-Trace species governing combustion and emissions," Proceedings of the combustion institute, vol. 31, pp. 77-98, 2007.

[24] S. V. Manyele and I. S. Kagonji, "Analysis of medical waste incinerator performance based on fuel consumption and cycle times," 2012.

[25] D. Pal, "A numerical model of acidification of raindrops by oxidation of SO2," International journal of environmental studies, vol. 57, pp. 167-177, 2000.

[26] EPA. (1998, Nitrogen Oxides (NOx), Why and How They Are Controlled.
[27] D. W. Schindler, "Effects of acid rain on freshwater ecosystems," Science(Washington), vol. 239, pp. 149-157, 1988.

[28] T. A. Haines, "Acidic precipitation and its consequences for aquatic ecosystems: a review," Transactions of the American Fisheries Society, vol. 110, pp. 669-707, 1981.

[29] C. T. Driscoll, K. M. Driscoll, M. J. Mitchell, and D. J. Raynal, "Effects of acidic deposition on forest and aquatic ecosystems in New York State," Environmental Pollution, vol. 123, pp. 327-336, 2003.

[30] A. A. Mustabeen and I. Khan, "Phytotoxic effect of simulated acid rain on black gram," Archives of Phytopathology and Plant Protection, vol. 44, pp. 1343-1346, 2011.

[31] E. M. Khamala and A. A. Alex, "Municipal Solid waste composition and characteristics relevant to the waste to energy disposal method for Nairobi City," Global Journal of Engineering, Design and Technology, vol. 2, pp. 1-6, 2013.

[32] T. Ogwueleka, "Municipal solid waste characteristics and management in Nigeria," Iranian Journal of Environmental Health Science \& Engineering, vol. 6, pp. 173-180, 2009.

[33] K. O. Boadi and M. Kuitunen, "Environmental and health impacts of household solid waste handling and disposal practices in third world cities: the case of the Accra Metropolitan Area, Ghana," Journal of environmental health, vol. 68, pp. 32-36, 2005.

[34] D. Hoornweg and P. Bhada-Tata, "What a waste: A Global review of solid waste Management," USA2012.

[35] ASTM, "ASTM D5231-92, Standard Test Method for the Determination of the Composition of Unprocessed Municipal Solid Waste," ed. West Conshohocken, PA: ASTM International, 2003.

[36] A. Omari, M. Said, K. Njau, G. John, and P. Mtui, "Energy recovery routes from Municipal Solid Waste, A case study of Arusha-Tanzania," Journal of Energy Technologies and Policy, vol. 4, pp. 1-7, 2014.

[37] Y. Zhao, W. Xing, W. Lu, X. Zhang, and T. H. Christensen, "Environmental impact assessment of the incineration of municipal solid waste with auxiliary coal in China," Waste management, vol. 32, pp. 1989-1998, 2012.

[38] K. C. Mukwana, S. R. Samo, M. M. Tunio, A. Q. Jakhrani, and M. R. Luhur, "Study of Energy potential from municipal solid waste of Mirpurkhas City," Journal of engineering, Science \& Technology, vol. 13, pp. 26-28, 2014.

[39] L. Laureano-Perez, F. Teymouri, H. Alizadeh, and B. E. Dale, "Understanding factors that limit enzymatic hydrolysis of biomass," Applied Biochemistry and Biotechnology, vol. 124, pp. 1081-1099, 2005.

[40] Y. H. P. Zhang, S. Y. Ding, J. R. Mielenz, J. B. Cui, R. T. Elander, M. Laser, et al., "Fractionating recalcitrant lignocellulose at modest reaction conditions," Biotechnology and Bioengineering, vol. 97, pp. 214-223, 2007.

[41] D. Fengel and G. Wegener, Wood: chemistry, ultrastructure, reactions: Walter de Gruyter, 1983.

[42] T. Atabarut and E. Ekinci, "Thermal treatment of landfill leachate and the emission control," Journal of Environmental Science and Health Part A, vol. 41, pp. 1931-1942, 2006. 
[43] A. Omari, M. Said, K. Njau, G. John, and P. Mtui, "Energy recovery routes from Municipal Solid Waste, A case study of Arusha-Tanzania.," Journal of Energy Technology and Policy, vol. 4, pp. 1-7, 2014.

[44] G. Stubenberger, R. Scharler, S. Zahirović, and I. Obernberger, "Experimental investigation of nitrogen species release from different solid biomass fuels as a basis for release models," Fuel, vol. 87, pp. 793-806, 2008.
[45] W.-H. Chen and J.-C. Chen, "Combustion characteristics and energy recovery of a small mass burn incinerator," International communications in heat and mass transfer, vol. 28, pp. 299-310, 2001.

[46] P. Mtui, "Computational Analysis of a Fixed Bed Thermal Oxidizer for Solid Wastes Disposal," Advanced Materials Research, vol. 699, pp. 326-334, 2013. 